\title{
PERFORMANCE INDICATORS ASSESSMENT OF INSURANCE COMPANIES IN NON-LIFE INSURANCE BY APPLYING DECOMPOSITION MULTI-CRITERIA METHODS
}

\author{
[Hodnocení ukazatelů úrovně hospodaření pojištoven v neživotním pojištění \\ aplikací dekompozičních metod]
}

\author{
Martina Borovcová ${ }^{1}$, Zuzana Folvarschi $^{2}$ \\ ${ }^{1}$ Vysoká škola báňská-Technická univerzita Ostrava, Ekonomická fakulta, Sokolská 33, 70121 Ostrava \\ Email:martina.borovcova@vsb.cz
}

${ }^{2}$ Vysoká škola báňská-Technická univerzita Ostrava, Ekonomická fakulta, Sokolská 33, 70121 Ostrava Email:zuzana.folvarschi.st@vsb.cz

\begin{abstract}
The aim of the article is to determine and verify the key indicators of the assessment of the level of management of non-life insurance companies by applying multi-criteria decomposition methods. The specific indicators considered include standard financial analysis indicators (equity ratio, total debt ratio, return on equity indicator and return on assets), specific financial indicators of insurance companies (claims ratio, capital adequacy ratio, technical adequacy ratio, solvency ratio indicator and more) and indicators that are used to analyze the level of the insurance market (gross premiums written, net premiums earned and number of insurance contracts concluded). Firstly, multicriteria decomposition methods are described: analytical hierarchical process and analytical network process. Both approaches are described including the calculation procedure. Subsequently, they are applied in determining the preferences of indicators of the assessment of the level of management of insurance companies. Our results show the resulting preferences of individual indicators for assessing the level of performance of non-life insurance companies and key indicators. The most important indicators that can be described as the key indicators with a high preference are return on equity indicator, gross premiums written, return on assets, claims ratio and solvency ratio indicator.
\end{abstract}

Keywords: decomposition multi-criteria methods, insurance company, key assessment indicator, nonlife insurance.

JEL classification: $\mathrm{C} 02, \mathrm{C} 4, \mathrm{G} 2, \mathrm{G} 11$

Received: 17.1.2020; Reviewed: 6.2.2020; 22.2.2020; Accepted: 9.9.2020

\section{Úvod}

Součástí ekonomiky státu je, mimo jiných specifických oblastí, pojištovnictví. Nezbytnou podmínkou efektivního fungování celého pojišstovnictví je efektivní fungování základních subjektů této oblasti, kterými jsou chápány pojištovny. Snaha o efektivní fungování se pak bezprostředně odráží $\mathrm{v}$ hospodaření pojišt'oven, př́ípadně měnící se úrovni hospodaření. K posouzení hospodaření pojišt'oven je využívána, mimo jiné, finanční analýza, jejímž cílem je, jak uvádí Vávrová (2014) identifikovat jakoukoli slabost ve finančním zdraví, jež by mohla vést $\mathrm{k}$ budoucím potížím, a určit silnou stránku, kterou lze v dané komerční pojišt'ovně zužitkovat v budoucnu.

Základním nástrojem pro provedení finanční analýzy pojištoven jsou ukazatele hodnocení úrovně hospodaření pojišt'oven, zpravidla poměrové ukazatele. Výpočet těchto poměrových ukazatelů není nijak náročný. Problémem však může být, mimo jiné, správná interpretace výsledků. V rámci finanční analýzy pojištoven je vhodné provést srovnání za delší časové období nebo př́padně porovnat dosažené hodnoty s konkurenční pojištovnou. Dalším důležitým faktorem, který může ovlivnit interpretaci a hodnocení analyzovaného subjektu pak 
je skutečnost rozdílné důležitosti ukazatelů použitých k hodnocení úrovně hospodaření pojišt'ovny. V kategorii těchto ukazatelů jsou zastoupeny, jak uvádí Ducháčková (2015), nejen ukazatele používané pro hodnocení hospodaření podniků obecně, jako jsou např. ukazatel rentability aktiv či ukazatel rentability vlastního kapitálu, o nichž se zmiňuje např. Dluhošová (2010), ale také ukazatele specifické pro oblast pojišt'ovnictví a to např. ukazatel pojištěnosti a ukazatel předepsaného pojistného, o nichž se zmiňují Dash, Pradhan, Maradana, Gaurav, Zaki and Jayakumar (2018) nebo Pradhan, Arvin and Norman (2015), ukazatel škodovosti, ukazatel pojistného plnění a další, jak uvádí Thoys (2010) a Zweifel and Eisen (2012). V neposlední řadě je pak hospodaření pojišs'oven analyzováno pomocí ukazatelů specifických pro hodnocení pojišt'oven s ohledem na odvětví pojištění, které provozují. Těmi se zabývají a ve své práci je analyzují např. Kwon and Wolfrom (2016).

Protože soubor hodnocených ukazatelů může v konečné fázi čítat značného množství hodnocených ukazatelů a analýza se může stávat nepřehlednou a složitou, vzniká prostor pro určení klíčových ukazatelů, což s sebou nese potřebu stanovit preference jednotlivých ukazatelů. Využitelnou se $\mathrm{v}$ takové situaci potřeby stanovení důležitosti jednotlivých ukazatelů jeví aplikace dekompozičních metod vícekriteriálního rozhodování, kdy pomocí konkrétních metod mohou být stanoveny preference, důležitost, jednotlivých ukazatelů. Tím se proces hodnocení úrovně hospodaření může stát komplexnějším.

Cílem článku je, s ohledem k výše uvedeným skutečnostem, stanovení preferencí vybraných ukazatelů hodnocení úrovně hospodaření pojištoven v neživotním pojištění pomocí dekompozičních metod vícekriteriálního rozhodování a určení klíčových ukazatelů.

\section{Teoretická a metodická východiska vícekriteriálního rozhodování}

Snaha o exaktní formulaci rozhodovacích procesů se začíná objevovat s rozvojem matematiky a ekonomie v 18. století. Základem pro budoucí rozvoj hodnocení se zřetelem na více kritérií a důsledek či efekt rozhodnutí, založeným na funkci užitku, se v tomto období stala teorie švýcarského matematika a fyzika Daniela Bernoulliho (1954). Důležitý prvek vícekriteriálnosti v rozhodování je zmiňován již v roce 1906 italským ekonomem, Vilfredem Paretem v jeho monografii Manuale di Economia Politica, Pareto (1971).

Od poloviny 20. století dochází $\mathrm{k}$ exponenciálnímu vývoji $\mathrm{v}$ oblasti vícekriteriálního rozhodování a začínají být vydávány další publikace na toto téma. Př́kladem a jedním z nejvíce respektovaných děl je soubor publikací zaměřených na vícekriteriální rozhodování a popis analytického hierarchického procesu (AHP, Analytic Hierarchy Process), viz subkapitola 2.3., Thomase L. Saatyho. Tento metodický postup byl popsán profesorem Pensylvánské univerzity v Pittsburghu v USA a jeho spolupracovníky v 80. a 90. letech. Jde o metodu dnes široce používanou v rozhodovací praxi. Řadu let se zejména ve společenských vědách používá tzv. Saatyho metoda párového porovnání, kterou zmiňuje např. Ramík (1999), Brožová, Houška a Šubrt (2014), Fotr, Švecová a kol. (2010) či Zmeškal, Dluhošová a Tichý (2013). Ta tvoří páteř konzistentní metodologie vícekriteriálního hodnocení nazvané AHP. V posledních dvou desetiletích vede vývoj dřive zmíněných metod ke vzniku stochastických a fuzzy verzí.

Základy rozhodovacího procesu popisuje Saaty (2006). Jeho monografie je výsledkem dlouholetého výzkumu zpo̊sobu rozhodování. Zmiňuje základní způsoby rozhodování, podrobně se věnuje principu AHP a následně principu analytického sít’ového procesu (ANP, Analytic Network Process), viz subkapitola 2.3. V př́ípadě obou procesů je v rozhodování použito procesní zobecnění rozhodovacího problému do jednotlivých úrovní hierarchie rozhodovacího procesu. Hodnoty kritérií či jejich váhy jsou stanoveny postupnou dekompozicí 
od cíle až po kritéria a varianty. Rozdíl je ve vazbách, přičemž v AHP mohou být tyto vazby lineární, ve tvaru pyramidy, zatímco v ANP jde o vazby nelineární s uplatněním zpětných vazeb.

Pro oba př́stupy je shodným princip párového porovnání, který Saaty (2009) využívá jak pro stanovení vah kritérií, tak pro výběr varianty samotné. Upozorňuje rovněž na důležitost adekvátnosti stanovených kritérií i variant rozhodování, viz Zmeškal (2012), (2014). Mimo jiné zdůrazňuje nezbytnost respektování intenzity významnosti mezi srovnávanými páry jak kritérií, tak variant řešení. Doporučuje základní škálu hodnot odpovídajících př́slušné prioritě v páru porovnávaného kritéria či varianty. Jeho doporučení se týkají rovněž zásad uplatnění jednotlivých hodnot škály.

Problémem při aplikaci metod AHP a ANP může být, jak upozorňuje Saaty (2010), nekonzistentnost sestavovaných matic. Doporučuje proto testování konzistence matic, navrhuje postupy pro toto testování a určuje rovněž hraniční hodnotu, při které je možno považovat matici za konzistentní.

Nová filozofie řešení složitých rozhodovacích problémů je pak myšlenkou, kterou Saaty (2012) uplatňuje. Myšlenka využití analytického hierarchického procesu pro rozhodování v komplexně vnímaném světě nabízí možnosti řešení v koncepci rozhodování složitých problémů na úrovni ekonomik států či jejich uskupení pomocí nepříliš náročného přístupu zahrnujícího pouze jednoduchou matematickou aritmetiku a počítačové aplikace. Přináší tak do značné míry nový pohled na rozhodovací proces.

\section{Rozhodovací proces a vícekriteriální rozhodování}

Rozhodnutí je v teorii vícekriteriální analýzy variant chápáno jako výběr jedné nebo více variant z množiny variant prŕípustných. Rozhodování pak jako proces, $\mathrm{k}$ rozhodnutí vedoucí. Při výběru je nutné, aby rozhodovatel při stanovení kritérií pro rozhodování, jejich hodnocení a výběru variant postupoval maximálně objektivně, $\mathrm{k}$ čemuž slouží aparát různých postupů a analýz. V rámci řešení úloh vícekriteriálního rozhodování je možno se setkat se dvěma př́stupy: vícekriteriálním hodnocením variant (MADM, Multiple Attribute Decision Making) a vícekriteriálním optimálním programování (MODM, Multiple Objective Decision Making). $\mathrm{V}$ př́padě modelu MADM jsou varianty určeny diskrétně, typicky se používají pro hodnocení finanční úrovně podniku. Oproti tomu v modelu MODM jsou varianty vymezeny spojitě pomocí omezujících podmínek a účelových funkcí. Jako prríklad lze uvést optimální složení investičního portfolia.

Podle počtu subjektů lze rozdělit rozhodování na př́pady s jedním rozhodovatelem (individuální rozhodování), menší skupinou (group decision-making) a velkou sociální skupinou (social choise).

Cílem vícekriteriálního rozhodování může být nalezení nejlepší (optimální) varianty, uspořádání variant od nejlepší po nejhorší, uspořádání variant do hierarchických shluků, rozdělení variant na dvě skupiny (akceptovatelné a neakceptovatelné) nebo stanovení množiny efektivních variant nebo vyloučení neefektivní varianty.

Pro výpočty a porovnání je nutné, aby zadané hodnoty kritérií $y_{i j}$ byly normalizovány do jednotkového intervalu, tedy $x_{i j} \in[0 ; 1]$. Obecně je možné tyto hodnoty získat z dílčích funkcí utility, $x_{i j}=u\left(y_{i j}\right)$. 


\subsection{Typologie a řešení vícekriteriálních úloh}

V závislosti na kombinaci způsobů stanovení hodnot kritérií a preferencí jednotlivých kritérií lze stanovit řadu typů úloh, které jsou zobrazeny v Tabulce 1 .

Tabulka 1: Kombinace způsobů stanovení hodnot a preferencí kritérií

\begin{tabular}{|c|c|c|c|c|c|c|c|c|}
\hline \multirow{3}{*}{\multicolumn{4}{|c|}{$\begin{array}{c}\text { Kombinace způsobů stanovení variant a } \\
\text { kritérií }\end{array}$}} & \multicolumn{5}{|c|}{ Preference dílčích kritérií } \\
\hline & & & & \multirow{2}{*}{ bez } & ordinální & kardinální & \multicolumn{2}{|c|}{ párové } \\
\hline & & & & & pořadí & bodová & Fuller & Saaty \\
\hline \multirow{6}{*}{$\begin{array}{c}\text { Hodnoty } \\
\text { kritérií } \\
\text { u } \\
\text { variant }\end{array}$} & & & & \multirow{6}{*}{ I. } & & \multirow{2}{*}{\multicolumn{3}{|c|}{ II. }} \\
\hline & Kardinální & kvantitativní & $\mathrm{a}$ & & & & & \\
\hline & Ordinální & pořadí & $\mathrm{b}$ & & III. & & & \\
\hline & Kardinální & bodová & $\mathrm{c}$ & & \multirow{3}{*}{ IV. } & III. & \multicolumn{2}{|c|}{ IV. } \\
\hline & \multirow{2}{*}{ Párové } & Fuller & $\mathrm{d}$ & & & & III. & \\
\hline & & Saaty & $\mathrm{e}$ & & & & & III. \\
\hline
\end{tabular}

Zdroj: Zmeškal, Dluhošová a Tichý (2013, s. 44)

Z výše uvedené tabulky je patrné, že lze rozlišit čtyři skupiny kombinací. V I. skupině se jedná o úlohy, které jsou bez preference kritérií, II. skupina obsahuje úlohy s kvantitativně určenými hodnotami kritérií, do III. skupiny patří úlohy, kde jsou, jak preference kritérií, tak hodnoty kritérií stanoveny stejnou metodou. Poslední IV. skupina zahrnuje všechny ostatní kombinace.

Řešení vícekriteriálního rozhodování vzniká kombinací stanovení hodnot kritérií, preferencí kritérií, normalizace kritérií a typem souhrnného kritéria. Př́́kladem metod, které jsou založeny na vícekriteriální funkci užitku, jsou metoda váženého součtu (WSM, Weighted Sum Model a metoda váženého součinu (WPM, Wighted Product Model). Mezi metody založené na kompromisním kritériu patří např. metoda TOPSIS (Technique for Other Preference by Similarity to an Ideal Solution), VIKOR (Compromise Ranking Method) a metoda GRA (Grey Relation Analysis). Souhrnné (fuzzy) preferenční relace zahrnují metodu Oreste, Electre a Promethe. Zvláštní skupinou jsou vícestupňové dekompoziční metody, které vychází ze Saatyho metody párového srovnání. Jedná se o AHP a ANP. Pro dekompoziční metody je typické, že váhy kritérií jsou stanoveny postupnou dekompozicí od cíle, globálních skupin kritérií, subkritérií až po prvotní neboli dílčí kritéria a varianty. Tyto zmíněné vazby mohou být lineární, AHP, nebo nelineární, ANP.

\subsection{Saatyho metoda párového porovnání}

Aplikace Saatyho metody párového srovnání pro stanovení vah kritérií spočívá ve dvou krocích. V prvním kroku je nutné stanovit preferenční vztahy dvojic kritérií včetně velikosti preference. V druhém kroku je již možné stanovit váhy jednotlivých kritérií. Saaty doporučuje využití bodové stupnice opatřené deskriptory, viz Tabulka 2.

Tabulka 2: Doporučená bodová stupnice s deskriptory

\begin{tabular}{|c|l|}
\hline Počet bodů & \multicolumn{1}{|c|}{ Deskriptor } \\
\hline 1 & Kritéria jsou stejně důležitá. \\
\hline 2 & První kritérium je mírně důležitější než druhé. \\
\hline 3 & První kritérium je středně důležitější než druhé. \\
\hline 4 & První kritérium je více než středně důležitější než druhé. \\
\hline 5 & První kritérium je silně důležitější než druhé. \\
\hline 6 & První kritérium je silněji významnější než druhé. \\
\hline 7 & První kritérium je prokazatelně významnější než druhé. \\
\hline 8 & První kritérium je prokazatelněji významnější než druhé. \\
\hline 9 & První kritérium je absolutně významnější než druhé. \\
\hline
\end{tabular}

Zdroj: vlastní zpracování dle Saaty (2010, s. 105) 
Výsledkem prvního kroku je získání pravé části Saatyho matice označované jako $S$.

$$
S=\left(\begin{array}{cccc}
1 & s_{12} & \cdots & s_{1 n} \\
1 / s_{12} & 1 & \cdots & s_{2 n} \\
\vdots & \vdots & \vdots & \vdots \\
1 / s_{1 n} & 1 / s_{2 n} & \cdots & 1
\end{array}\right) .
$$

Další prvky na diagonále jsou získány dle vztahu $S_{i i}=1$ pro všechna $i$, a prvky v levé dolní části matice dle vztahu $s_{j i}=\frac{1}{s_{i j}}$ pro všechna $i$ a $j$. Prvky $s_{j i}$ této matice jsou odhadem podílů vah kritérií $w_{j}$ a $w_{i}$ kde platí,

$$
s_{i j} \approx \frac{w_{i}}{w_{j}}
$$

Je-li známa Saatyho matice $S$, je možné stanovit váhy kritérií, a to exaktním nebo aproximativním způsobem. Exaktní způsob je založen na výpočtu vektoru matice relativních důležitostí nebo metodě nejmenších čtverců. Tento způsob je početně náročnější, a to hlavně u rozsáhlejších souborů. Jednodušším se jeví využití aproximativního způsobu. Potřebných odhadů je tak dosaženo pomocí výpočtu normovaných geometrických průměrů řádků matice $S$.

Pro ověření konzistentnosti matice lze využít koeficientu $C R$. Jeli $C R \leq 0,1$ pak je matice konzistentní. $C R$ je možné vypočítat dle vztahu,

$$
C R=\frac{C I}{R I}
$$

kde

$$
C I=\frac{\lambda_{\max }-N}{N-1}
$$

hodnotu charakteristického čísla $\lambda_{\max }$ je možné stanovit několika postupy. Jeden z možných postupů je dle vzorce,

$$
\lambda_{\max }=\frac{1}{N} \sum_{i}^{N}(S \cdot \vec{w})_{i} / w_{i}
$$

přičemž $\vec{w}$ je vektor a $(S \cdot \vec{w})_{i}$ je $i$-tý prvek vektoru. $R I$ (Random index) dosahuje hodnot v závislosti na počtu kritérií a je odvozen z empirického zkoumání. Hodnoty jsou zachyceny v Tabulce 3.

Tabulka 3: Hodnoty RI pro různý počet prvků

\begin{tabular}{|l|c|c|c|c|c|c|c|c|c|c|c|c|c|c|c|}
\hline $\mathrm{N}$ & 1 & 2 & 3 & 4 & 5 & 6 & 7 & 8 & 9 & 10 & 11 & 12 & 13 & 14 & 15 \\
\hline $\mathrm{RI}$ & 0,00 & 0,00 & 0,52 & 0,89 & 1,11 & 1,25 & 1,35 & 1,40 & 1,45 & 1,49 & 1,52 & 1,54 & 1,56 & 1,58 & 1,59 \\
\hline
\end{tabular}

Zdroj: vlastní zpracování dle Saaty (2010, s. 121) 


\subsection{Analytický hierarchický a analytický sít'ový proces}

Analytický hierarchický proces byl navržen americkým matematikem, profesorem Thomasem L. Saatym v roce 1980. Jedná se o metodu, která poskytuje rámec pro př́pravu účinných rozhodnutí ve složitých situacích s cílem zjednodušit a zrychlit přirozený rozhodovací proces. Metoda představuje rozklad složité nestrukturované situace na jednodušší komponenty. Dochází tedy k vytvoření hierarchického systému problému. Tento systém představuje rozšíření možností vícekriteriálního rozhodovacího systému. Na každé jednotlivé úrovni hierarchické struktury je použita Saatyho metoda kvantitativního párového srovnání. Ve své podstatě je pomocí subjektivního hodnocení přiřazena číselně vyjádřená hodnota jejich důležitosti.

Saatyho metodu AHP je možno využít pro jakýkoliv typ informace o preferenčních vztazích mezi komponenty modelu. Zásadní omezující podmínkou je, aby uživatel byl schopen stanovit nejen směr preference, ale i intenzitu vztahu mezi všemi komponenty. Označením hierarchická struktura se rozumí lineární struktura, která obsahuje několik úrovní a každá z úrovní obsahuje několik prvků. Uspořádání je provedeno od obecného ke konkrétnímu. Čím jsou prvky obecnější vzhledem k rozhodovacímu procesu, tím zaujímají v hierarchii vyšší úroveň a naopak. Nejvyšší úroveň obsahuje vždy jen jeden prvek, který definuje cíl analýzy. Tomuto zmíněnému prvku je přiřazena hodnota 1 , která je následně dále rozdělena mezi prvky na druhé úrovni. Podobně se postupuje až po nejnižší úroveň, viz Obrázek 1.

Analytický sít'ový proces byl vytvořen Thomasem L. Saatym v roce 1996 s cílem vytvořit univerzální nástroj pro řešení vícekriteriálních problémů. Metoda ANP je ve své podstatě zobecněním metody AHP. Typickým rysem metody AHP je nezávislost prvků, avšak u metody ANP je zohledněn zpětnovazební systém. Z této skutečnosti vyplývá, že se předpokládá vztah nejen mezi skupinami kritérií ale také mezi prvky uvnitř jednotlivých skupin. Struktura tohoto procesu je znázorněna v Obrázku 2.

Při řešení rozhodovacího problému pomocí AHP a ANP je v prvním kroku je nutné stanovit váhy neboli preference podskupin nebo ukazatelů s ohledem na účel práce, a to pomocí Saatyho metody párového srovnání. Následně může být proveden propočet globálních vah, které zahrnují dílčí váhy a součet těchto vah musí být roven jedné. Při výpočtu AHP je možné použít analytickou metodu nebo metodu supermatice. Jinak je tomu u ANP, kde musí být výpočet proveden pouze metodou supermatice. 
Obrázek 1: Grafické zobrazení metody AHP

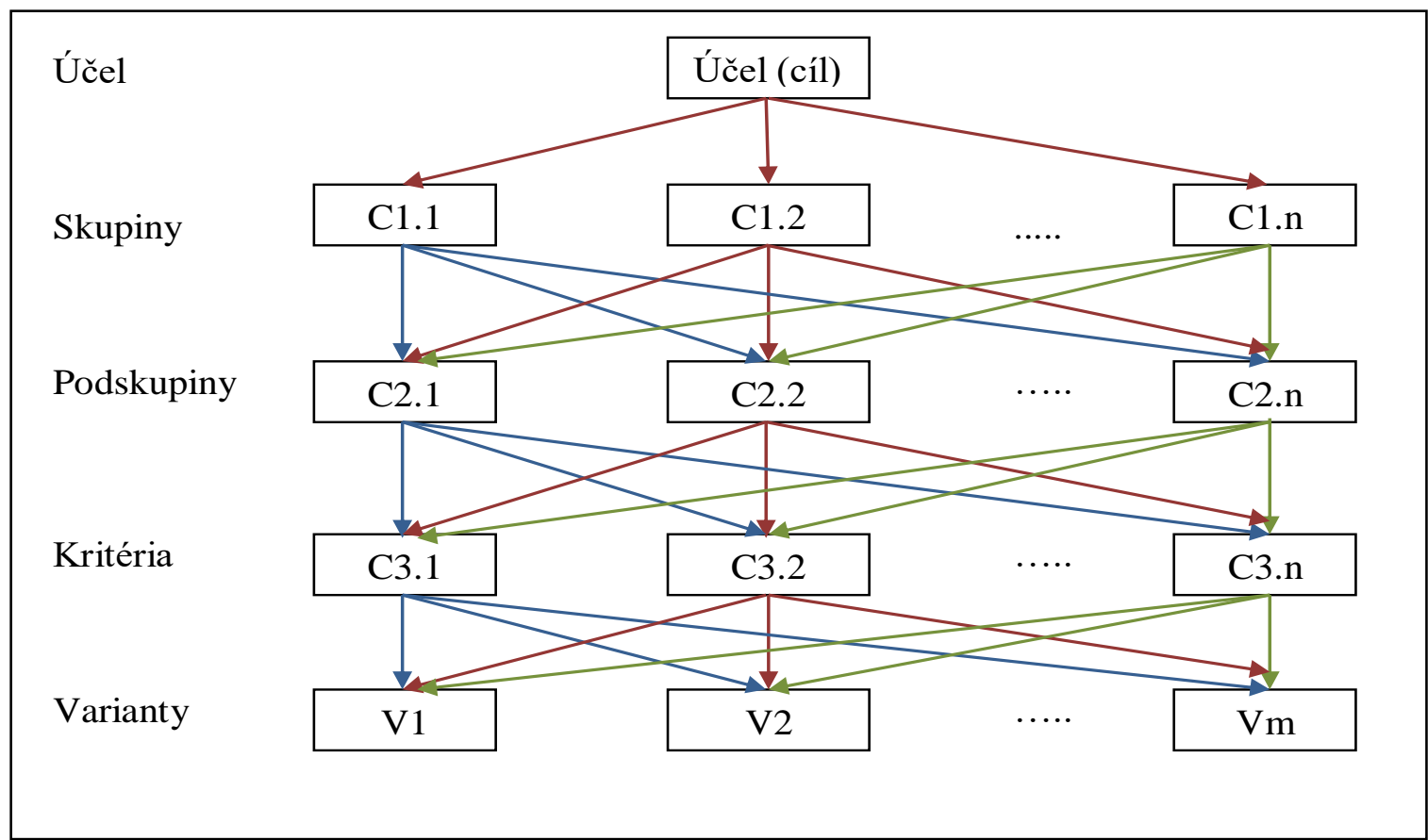

Zdroj: vlastní zpracování dle Zmeškal, Dluhošová a Tichý (2013, s. 47)

Pokud při řešení AHP aplikujeme analytickou metodu, váhy ukazatele podskupiny jsou získány dle vztahu $w_{i, j}^{;}=w_{i} \cdot w_{i, j}$, přičemž $w_{i, j}^{;}$je globální váha $j$-tého ukazatele $i$-té skupiny, $w_{i}$ je lokální váha $i$-té skupiny a $w_{i, j}$ je lokální váha $j$-tého ukazatele $i$-té skupiny. Tímto postupem lze získat všechny globální váhy prvotních ukazatelů.

Při aplikaci metody supermatice, jak pro metodu AHP, tak pro metodu ANP se výpočet skládá ze tří částí. První částí je sestavení výchozí supermatice $\mathrm{W}$, kdy jsou do sloupců zadávány lokální normalizované váhy $w_{i, j}$ a lokální váhy kritérií $\mathrm{e}_{1,1}$ až $\mathrm{e}_{\mathrm{N}, \mathrm{N}}$ podle účelu řešení. Poté v rámci druhé části je výchozí supermatice transformována na váženou supermatici $\bar{W}$ tak, aby součty sloupců byly rovny jedné. Je tomu tak hlavně z početních důvodů, aby bylo možné najít konvergentní řešení. 
Obrázek 2: Grafické zobrazení metody ANP

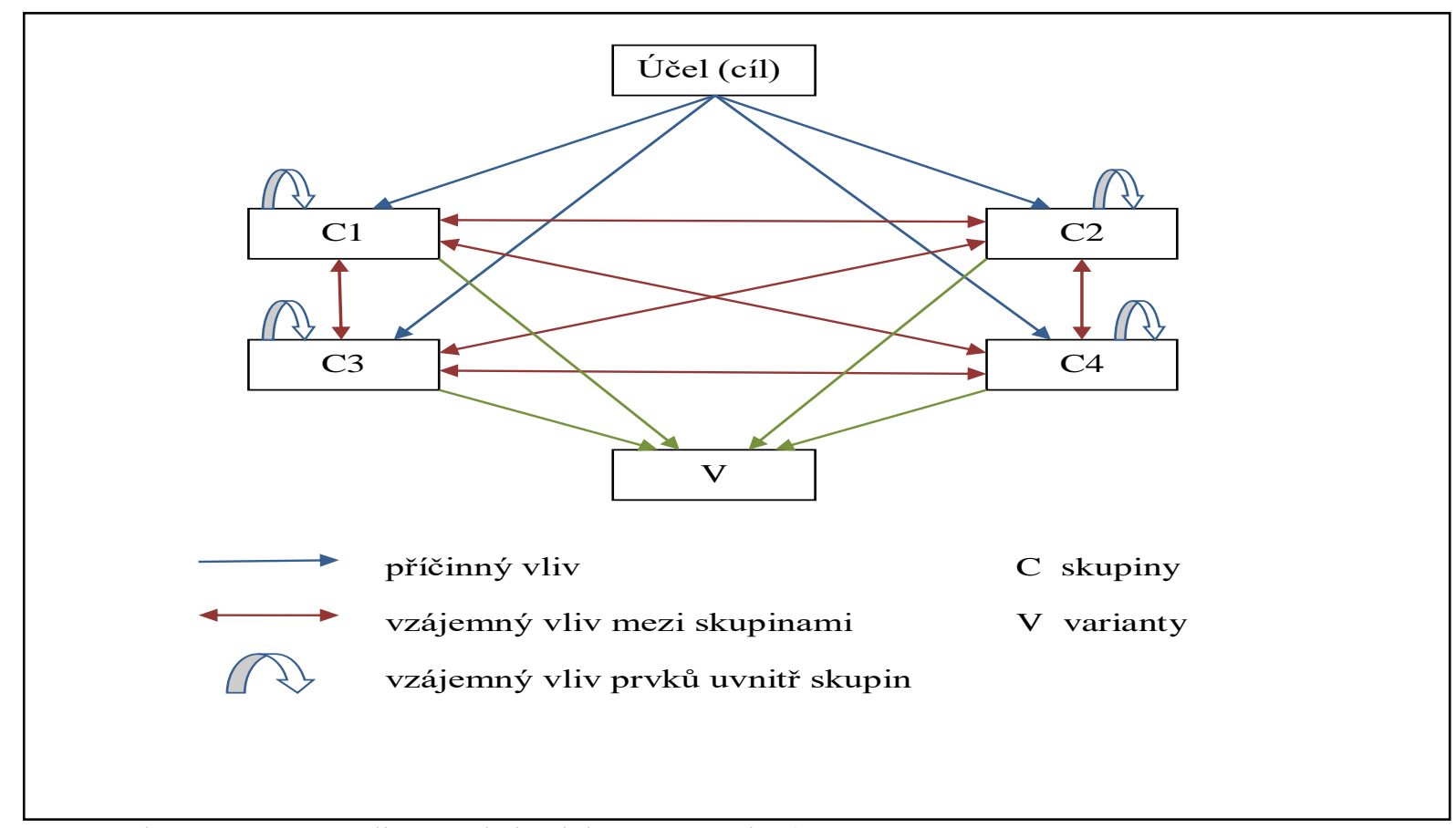

Zdroj: vlastní zpracování dle Zmeškal, Dluhošová a Tichý (2013, s. 47)

V poslední části je proveden přepočet finální supermatice $\bar{W}^{\infty}$. V př́ípadě necyklické vážené matice takto, $\bar{W}^{\infty}=\lim _{\mathrm{k} \rightarrow \infty} \bar{W}^{k}$, kde $\bar{W}^{\infty}$ je finální supermatice, $\bar{W}^{k}$ je vážená supermatice bez existence cyklu umocnęná právě k-krát. U cyklické matice dle vzorce

$$
\bar{W}^{N}=\frac{1}{N} \sum_{k}^{N} \bar{W}^{k}
$$

Obrázek 3: Výchozí supermatice

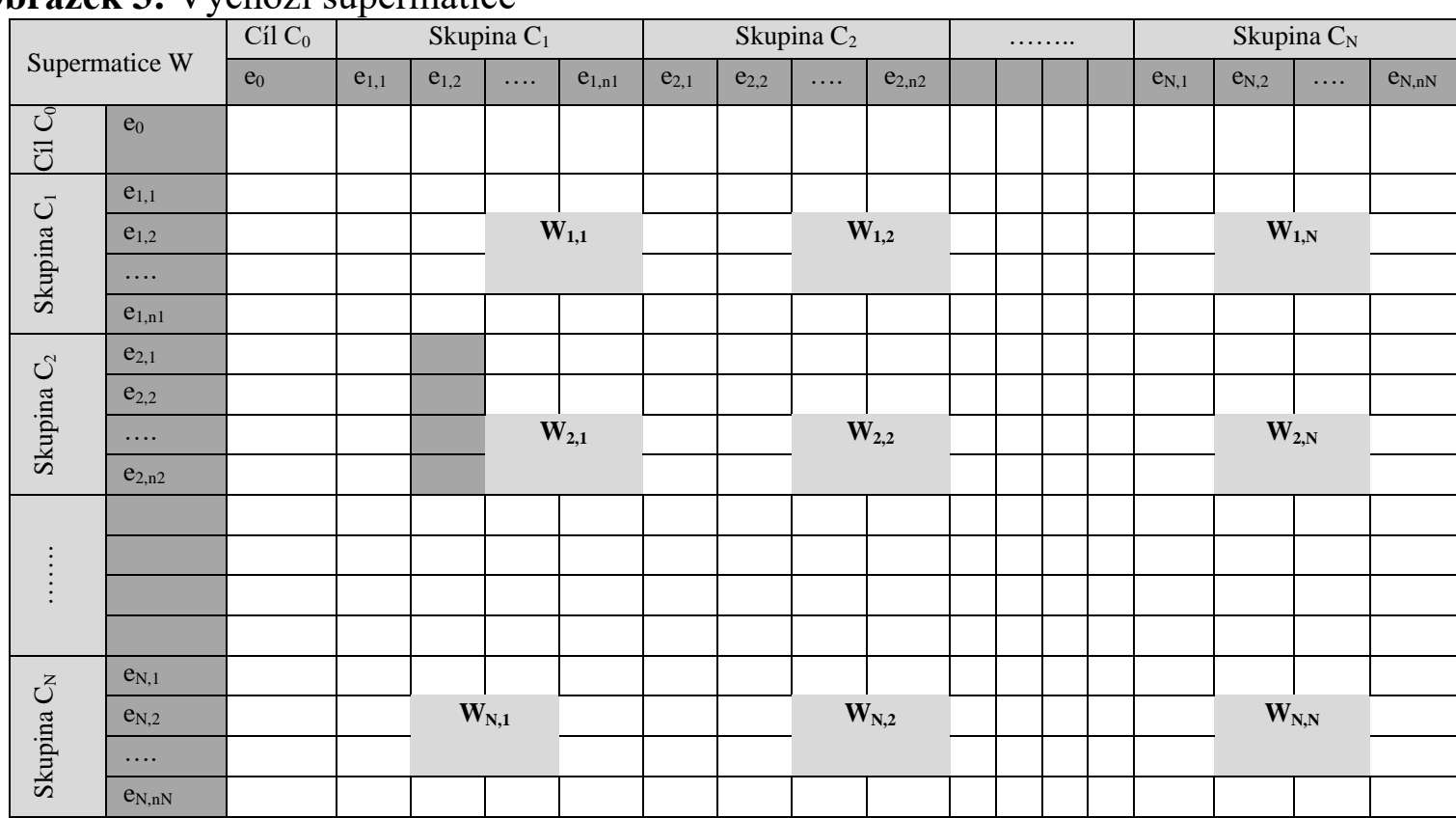

Zdroj: vlastní zpracování dle Zmeškal, Dluhošová a Tichý (2013, s. 48) 


\section{Hodnocení ukazatelů úrovně hospodaření pojišt'oven v neživotním pojištění}

Cílem finanční analýzy komerčních pojišt'oven je, jak již bylo uvedeno dřive, identifikovat jakoukoli slabost ve finančním zdraví, jež by mohla vést k budoucím potížím, a určit silnou stránku, kterou lze v dané komerční pojišt’ovně zužitkovat v budoucnu.

Základním nástrojem analýzy jsou ukazatele. Pro hodnocení hospodaření pojišt'oven jsou použity tři skupiny ukazatelů, a to standardní ukazatele finanční analýzy (I.), specifické finanční ukazatele pojišstoven (II.) a ukazatele, které jsou používány rovněž k analýze úrovně pojistného trhu (III.). První skupinu zastupují: ukazatel podílu vlastního kapitálu na aktivech (VKA), ukazatel celkové zadluženosti (ZAD), ukazatel rentability vlastního kapitálu (ROE) a ukazatel rentability aktiv (ROA), přičemž jde o jedny z nejdůležitějších ukazatelů pro hodnocení finanční situace jakéhokoli subjektu, pojišt'ovnu nevyjímaje. Pojišstovnictví je specifické v tom, že v oblasti životního a neživotního pojištění jsou jisté odlišnosti v rámci upisování, odškodňování a také při tvorbě technických rezerv, proto druhá skupina obsahuje: ukazatel škodního poměru (Claims ratio, CR), ukazatel doby obratu investic (Asset Leverage, AL), ukazatel podílu investic na aktivech (PIA), ukazatel investování technických rezerv (ITR), ukazatel přiměřenosti technických rezerv (Reserve Ratio, RR), solventnostní poměrový ukazatel (Solvency Ratio, SR), ukazatel kapitálové vybavenosti pojišt'ovny (Technical Coverage Ratio, TCR) a ukazatel podílu technických rezerv na vlastním kapitálu (PTR). Do výběru ukazatelů bylo důležité zahrnout i takové ukazatele, které jsou specifické právě pro oblast pojištění a zachycují specifičnost prováděné pojištovací činnosti zastoupené specifickými hodnotami v ukazatelích jako jsou např. položky technických rezerv, finančního umístění, nákladů na pojistná plnění a dalších. Třetí skupina ukazatelů je pak zastoupena ukazatelem hrubého předepsaného pojistného (HPP), ukazatelem čistého zaslouženého pojistného (С̆ZP) a ukazatelem počtu uzavřených smluv (PUS). V př́ípadě těchto ukazatelů jde o ukazatele typické pro poměřování výkonnosti pojišt'oven, posuzování konkurenceschopnosti pojišt'oven, hodnocení úrovně celého pojistného trhu i pro mezinárodní srovnávání. Tyto ukazatele jsou rovněž používány v konstrukcích dalších poměrových ukazatelů.

Tabulka 4: Charakteristika ukazatelů hodnocení úrovně hospodaření

\begin{tabular}{|c|c|}
\hline Ukazatel & Charakteristika ukazatele \\
\hline Rentabilita vlastního kapitálu (ROE) & Čistý zisk/Vlastní kapitál \\
\hline Rentabilita aktiv (ROA) & Zisk před zdaněním a úroky/Aktiva \\
\hline Celková zadluženost (ZAD) & Cizí zdroje/Aktiva \\
\hline Podíl vlastního kapitálu na aktivech (VKA) & Vlastní kapitál/Aktiva \\
\hline Škodní poměr $(\mathrm{CR})$ & Náklady na pojistná plnění/Čisté zasloužené pojistné \\
\hline Solventnostní poměrový ukazatel (SR) & Vlastní kapitál/Čisté zasloužené pojistné \\
\hline Kapitálová vybavenost pojišt’ovny (TCR) & Vlastní kapitál + Technické rezervy/Čisté zasloužené pojistné \\
\hline Přiměřenost technických rezerv (RR) & Technické rezervy/Čisté zasloužené pojistné \\
\hline Dostatečnost technických rezerv (PTR) & Technické rezervy/Vlastní kapitál \\
\hline Investování technických rezerv (ITR) & Finanční umístění (investice)/Technické rezervy \\
\hline Podíl investic na aktivech (PIA) & Finanční umístění (investice)/Aktiva \\
\hline Doba obratu investic (AL) & Finanční umístění (investice)/Čisté zasloužené pojistné \\
\hline Hrubé předepsané pojistné (HPP) & $\begin{array}{c}\text { Suma všech částek pojistného vyplývající z pojistných smluv, } \\
\text { bez ohledu na pojistné období, ke kterému se vztahuje }\end{array}$ \\
\hline Čisté zasloužené pojistné (ČZP) & $\begin{array}{c}\text { Hrubé zasloužené pojistné očištěné o zajistné placené } \\
\text { zajistitelům }\end{array}$ \\
\hline Počet uzavřených pojistných smluv (PUS) & Počet uzavřených pojistných smluv \\
\hline
\end{tabular}


Provedena je aplikace vícekriteriálních dekompozičních metod. Aplikována je, jak metoda AHP, tak metoda ANP, která zohledňuje zpětnovazební systém. Datová základna pro zpracování rozhodovacího procesu a hodnocení ukazatelů byla vytvořena pomocí ČAP (2019) a ČNB (2019).

Tabulka 5: Stanovení preferencí skupin ukazatelů s ohledem na cíl (AHP, ANP)

\begin{tabular}{|l|c|c|c|r|r|r|r|}
\hline Cíl & I. & II. & \multicolumn{1}{|c|}{ III. } & geomean & váha $\mathrm{w}_{\mathrm{i}}$ & \multicolumn{1}{c|}{$\mathrm{S} \cdot \mathrm{W}$} & $(\mathrm{S} \cdot \mathrm{w}) / \mathrm{w}_{\mathrm{i}}$ \\
\hline I. & 1 & 2 & 4 & 2,000 & 0,558 & 1,685 & 3,018 \\
\hline II. & $1 / 2$ & 1 & 3 & 1,145 & 0,320 & 0,965 & 3,018 \\
\hline III. & $1 / 4$ & $1 / 3$ & 1 & 0,437 & 0,122 & 0,368 & 3,018 \\
\hline
\end{tabular}

Tabulka 6: Stanovení preferencí ukazatelů skupiny I. (AHP, ANP)

\begin{tabular}{|l|c|c|c|c|r|r|r|r|}
\hline SUFA & ROE & ROA & ZAD & VKA & geomean & váha $\mathrm{w}_{\mathrm{i}}$ & \multicolumn{1}{c|}{$\mathrm{S} \cdot \mathrm{w}$} & \multicolumn{1}{c|}{$(\mathrm{S} \cdot \mathrm{w}) / \mathrm{w}_{\mathrm{i}}$} \\
\hline ROE & 1 & 2 & 4 & 5 & 2,515 & 0,494 & 1,996 & 4,039 \\
\hline ROA & $1 / 2$ & 1 & 3 & 4 & 1,565 & 0,307 & 1,243 & 4,042 \\
\hline ZAD & $1 / 4$ & $1 / 3$ & 1 & 1 & 0,537 & 0,106 & 0,424 & 4,021 \\
\hline VKA & $1 / 5$ & $1 / 4$ & 1 & 1 & 0,473 & 0,093 & 0,374 & 4,027 \\
\hline
\end{tabular}

Tabulka 7: Stanovení preferencí ukazatelů skupiny II. (AHP, ANP)

\begin{tabular}{|l|c|c|c|c|c|c|c|c|r|r|r|r|}
\hline FUP & CR & SR & TCR & RR & PTR & ITR & PIA & AL & geomean & váha $\mathrm{w}_{\mathrm{i}}$ & $\mathrm{S} \cdot \mathrm{w}$ & $(\mathrm{S} \cdot \mathrm{w}) / \mathrm{w}_{\mathrm{i}}$ \\
\hline $\mathrm{CR}$ & 1 & 2 & 3 & 4 & 5 & 6 & 7 & 8 & 3,764 & 0,328 & 2,751 & 8,389 \\
\hline $\mathrm{SR}$ & $1 / 2$ & 1 & 2 & 3 & 4 & 5 & 6 & 7 & 2,662 & 0,232 & 1,915 & 8,259 \\
\hline TCR & $1 / 3$ & $1 / 2$ & 1 & 2 & 3 & 4 & 5 & 6 & 1,819 & 0,159 & 1,305 & 8,231 \\
\hline RR & $1 / 4$ & $1 / 3$ & $1 / 2$ & 1 & 2 & 3 & 4 & 5 & 1,223 & 0,107 & 0,878 & 8,240 \\
\hline PTR & $1 / 5$ & $1 / 4$ & $1 / 3$ & $1 / 2$ & 1 & 2 & 3 & 4 & 0,818 & 0,071 & 0,588 & 8,246 \\
\hline ITR & $1 / 6$ & $1 / 5$ & $1 / 4$ & $1 / 3$ & $1 / 2$ & 1 & 2 & 3 & 0,550 & 0,048 & 0,395 & 8,240 \\
\hline PIA & $1 / 7$ & $1 / 6$ & $1 / 5$ & $1 / 4$ & $1 / 3$ & $1 / 2$ & 1 & 2 & 0,376 & 0,033 & 0,271 & 8,266 \\
\hline AL & $1 / 8$ & $1 / 7$ & $1 / 6$ & $1 / 5$ & $1 / 4$ & $1 / 3$ & $1 / 2$ & 1 & 0,266 & 0,023 & 0,195 & 8,431 \\
\hline
\end{tabular}

Tabulka 8: Stanovení preferencí ukazatelů skupiny III. (AHP, ANP)

\begin{tabular}{|l|c|c|c|r|r|r|r|}
\hline UPT & HPP & \multicolumn{1}{c|}{ ČZP } & PUS & \multicolumn{1}{|c|}{ geomean } & váha $\mathrm{w}_{\mathrm{i}}$ & \multicolumn{1}{c|}{$\mathrm{S} \cdot \mathrm{w}$} & $(\mathrm{S} \cdot \mathrm{w}) / \mathrm{w}_{\mathrm{i}}$ \\
\hline HPP & 1 & 3 & 5 & 2,466 & 0,637 & 1,935 & 3,039 \\
\hline ČZP & $1 / 3$ & 1 & 3 & 1,000 & 0,258 & 0,785 & 3,039 \\
\hline PUS & $1 / 5$ & $1 / 3$ & 1 & 0,405 & 0,105 & 0,318 & 3,039 \\
\hline
\end{tabular}

U všech sestavených matic byla testována konzistentnost s pozitivním výsledkem.

Tabulka 9: Vypočtené hodnoty preferencí ukazatelů

\begin{tabular}{|c|c|c|c|c|c|}
\hline \multirow[t]{2}{*}{ Ukazatel } & \multirow[t]{2}{*}{ Skupinové } & \multirow[t]{2}{*}{ Lokální } & \multirow{2}{*}{$\begin{array}{c}\begin{array}{c}\text { Analytická } \\
\text { metoda }\end{array} \\
\text { AHP }\end{array}$} & \multicolumn{2}{|c|}{ Metoda supermatice } \\
\hline & & & & AHP & ANP \\
\hline Rentabilita vlastního kapitálu (ROE) & \multirow{4}{*}{$55,8 \%$} & $49,4 \%$ & $27,59 \%$ & $27,59 \%$ & $20,51 \%$ \\
\hline Rentabilita aktiv (ROA) & & $30,7 \%$ & $17,17 \%$ & $17,17 \%$ & $12,76 \%$ \\
\hline Celková zadluženost (ZAD) & & $10,6 \%$ & $5,89 \%$ & $5,89 \%$ & $4,38 \%$ \\
\hline Podíl vlastního kapitálu na aktivech (VKA) & & $9,3 \%$ & $5,19 \%$ & $5,19 \%$ & $3,86 \%$ \\
\hline Škodní poměr (CR) & \multirow{2}{*}{$32,0 \%$} & $32,8 \%$ & $10,48 \%$ & $10,48 \%$ & $11,61 \%$ \\
\hline Solventnostní poměrový ukazatel (SR) & & $23,2 \%$ & $7,41 \%$ & $7,41 \%$ & $8,21 \%$ \\
\hline
\end{tabular}




\begin{tabular}{|c|c|c|c|c|c|}
\hline Kapitálová vybavenost pojišt'ovny (TCR) & & $15,9 \%$ & $5,07 \%$ & $5,07 \%$ & $5,61 \%$ \\
\hline Přiměřenost technických rezerv (RR) & & $10,7 \%$ & $3,41 \%$ & $3,41 \%$ & $3,77 \%$ \\
\hline Dostatečnost technických rezerv (PTR) & & $7,1 \%$ & $2,28 \%$ & $2,28 \%$ & $2,52 \%$ \\
\hline Investování technických rezerv (ITR) & & $4,8 \%$ & $1,53 \%$ & $1,53 \%$ & $1,70 \%$ \\
\hline Podíl investic na aktivech (PIA) & & $3,3 \%$ & $1,05 \%$ & $1,05 \%$ & $1,16 \%$ \\
\hline Doba obratu investic (AL) & & $2,3 \%$ & $0,74 \%$ & $0,74 \%$ & $0,82 \%$ \\
\hline Hrubé předepsané pojistné (HPP) & \multirow{3}{*}{$12,2 \%$} & $63,7 \%$ & $7,77 \%$ & $7,77 \%$ & $14,70 \%$ \\
\hline Čisté zasloužené pojistné (ČZP) & & $25,8 \%$ & $3,15 \%$ & $3,15 \%$ & $5,96 \%$ \\
\hline Počet uzavřených pojistných smluv (PUS) & & $10,5 \%$ & $1,28 \%$ & $1,28 \%$ & $2,42 \%$ \\
\hline$\sum$ & $100,0 \%$ & & $100,00 \%$ & $100,00 \%$ & $100,00 \%$ \\
\hline
\end{tabular}

Zdroj: vlastní zpracování

Jak je patrné z Tabulky 9, výsledky AHP vypočtené, jak analytickou metodou, tak metodou supermatice jsou totožné. Výsledky ANP metody jsou rozdílné, protože tato metoda zohledňuje zpětnovazební systém. $Z$ dosažených výsledků je patrné, že nejvyšší váhu dle obou metod má ukazatel ROE. Naopak nejnižší váhu má dle obou použitých metod ukazatel AL. Pořadí důležitosti všech analyzovaných ukazatelů je uvedeno v Tabulce 10.

Tabulka 10: Výsledné pořadí analyzovaných ukazatelů úrovně hospodaření

\begin{tabular}{|l|c|c|}
\hline \multicolumn{1}{|c|}{ Ukazatel } & Pořadí dle AHP & Pořadí dle ANP \\
\hline Rentabilita vlastního kapitálu (ROE) & 1. & 1. \\
\hline Rentabilita aktiv (ROA) & 2. & 3. \\
\hline Škodní poměr (CR) & 3. & 4. \\
\hline Hrubé předepsané pojistné (HPP) & 4. & 2. \\
\hline Solventnostní poměrový ukazatel (SR) & 5. & 5. \\
\hline Celková zadluženost (ZAD) & 6. & 8. \\
\hline Podíl vlastního kapitálu na aktivech (VKA) & 7. & 9. \\
\hline Kapitálová vybavenost pojištovny (TCR) & 8. & 7. \\
\hline Přiměřenost technických rezerv (RR) & 9. & 10. \\
\hline Čisté zasloužené pojistné (ČZP) & 10. & 6. \\
\hline Dostatečnost technických rezerv (PTR) & 11. & 11. \\
\hline Investování technických rezerv (ITR) & 12. & 13. \\
\hline Počet uzav̌̌ených pojistných smluv (PUS) & 13. & 12. \\
\hline Podíl investic na aktivech (PIA) & 14. & 14. \\
\hline Doba obratu investic (AL) & 15. & 15. \\
\hline
\end{tabular}

Zdroj: vlastní zpracování

\section{Závěr}

Předmětem našeho výzkumu je rozšsiřené použití dekompozičních metod vícekriteriálního rozhodování. Pojistný trh či výkonnost jeho subjektů je běžně vyhodnocována řadou ukazatelů, nikdo však dosud neřeší intenzitu jejich významu s možností určení klíčových ukazatelů. Využitelnost výsledků je zřejmá jak pro pojišstovny samotné, respektive jejich analytiky a management, tak pro jejich investory. Svou důležitost však mají také pro další subjekty pojistného trhu jako asociace pojišt'oven, státní dozor či orgán regulátora. Úroveň klíčových ukazatelů by mohla být i zajímavým kritériem výběru pojišt'ovny, respektive produktů pojišt’ovny budoucím klientem, tedy pojistníkem či pojištěným. Oblastí výzkumu bylo zvoleno neživotní pojištění, respektive hospodaření subjektů provozujících neživotní pojištění. 
Cílem článku proto bylo stanovit preference ukazatelů hodnocení úrovně hospodaření pojišt'oven v neživotním pojištění pomocí multi-kriteriálních metod AHP a ANP na základě Saatyho metody párového srovnání a vybrat klíčové ukazatele.

Byly popsány metody AHP a ANP, založené na Saatyho metodě párového srovnání. Následně byla použita analytická metoda a metoda supermatice. Bylo zjištěno, že oba přístupy $\mathrm{k}$ AHP a ANP vedou k podobným výsledkům v pořadí preferencí. Výsledky ukázaly, že konečné pořadí dle AHP, ANP pro jednotlivé skupiny ukazatelů bylo mírně odlišné.

Nejdůležitější ukazatele, které je možné označit jako klíčové a jejichž preference je vysoká, $(\operatorname{nad} 7 \%)$, jsou ROE $(20,51 \%), \operatorname{HPP}(14,70 \%), \operatorname{ROA}(12,76 \%), \mathrm{CR}(11,61 \%)$ a SR $(8,21 \%)$. Uváděné procentní hodnoty byly zjištěny metodou ANP. Mezi ukazatele středně preferované, s mírou preference vyšší než $3 \%$, se řadí ukazatel čistého zaslouženého pojistného, kapitálové vybavenosti pojišt'ovny, celkové zadluženosti, podílu vlastního kapitálu na aktivech a přiměřenosti technických rezerv. Kategorie nízko preferovaných ukazatelů pak s mírou preference menší než $3 \%$ tvoří ukazatel dostatečnosti technických rezerv, počtu uzavřených pojistných smluv, investování technických rezerv, podílu investic na aktivech a doby obratu investic.

\section{Poděkování}

Tento př́spěvek byl podpořen Projektem SGS VŠB-TU Ostrava SP2019/132 "Finanční rozhodování podniků a finančních institucí za rizika II”.

\section{Literatura}

[1] BERNOULLI, D., 1954. Speciman theorie novae de mensura sortis. Connentarii Academiae Scientarum Imperialis Petropolitanae 5(1738), pp. 175-192. [English translation by L. Somera: Exposition of a New Theory of Risk Evaluation, Econometrica 22, pp. 23-36].

[2] BROŽOVÁ, H., M. HOUŠKA a T. ŠUBRT, 2014. Modely pro vícekriteriální rozhodování. 1. vyd. Praha: Česká zemědělská univerzita. ISBN 978-80-213-1019-3.

[3] CIPRA, T., 2013. Finanční ekonometrie. 2. vyd. Praha: Ekopress. ISBN 978-80-8692993-4.

[4] DASH, S., R. P. PRADHAN, R. P. MARADANA, K. GAURAV, D. B. ZAKI and M. JAYAKUMAR, 2018. Insurance market penetration and economic growth in Eurozone countries: Time series evidence on causality. Future Business Journal [online]. 4 (1), 5067 [vid. 28. prosince 2017]. ISSN 2314-7210. Dostupné z: https://www.sciencedirect.com/science/article/pii/S2314721017301251

[5] DLUHOŠOVÁ, D., 2010. Finanční řizení a rozhodování podniku: analýza, investování, oceňování, riziko, flexibilita. 3. vyd. Praha: Ekopress. ISBN 978-80-86929-68-2.

[6] DUCHÁČKOVÁ, E., 2015. Pojištění a pojištovnictví. 1.vyd. Praha: Ekopress. ISBN 97880-87865-25-5.

[7] FOTR, J., L. ŠVECOVÁ a kol., 2010. Manažerské rozhodování: postupy, metody a nástroje. 2. vyd. Praha: Ekopress. ISBN 978-80-86929-59-0.

[8] KWON, W. J. and L. WOLFROM, 2016. Analytical tools for the insurance market and macro-prudential surveillance. OECD Journal: Financial Market Trends [online]. 2016/1(110), 1-47 [vid. 10. listopadu 2016]. ISSN 1995-2872. Dostupné z: 
https://www.oecd-ilibrary.org/docserver/fmt-2016-

5jln6hnvwdzn.pdf?expires $=1548858891 \& i d=i d \&$ accname $=0 i d 008476 \&$ checksum $=$ BE36 FC3A9166AE5312EB370BF5A46D5D

[9] PARETO, V., 1971. Manual of political economy (manual di economia politica). New York: Kelley.

[10] PRADHAN, R. P., M. B. ARVIN and N. R. NORMAN, 2015. Insurance development and the finance-growth nexus: Evidence from 34 OECD countries. Journal of Multinational Financial Management [online]. 31, 1-22 [vid. 14. února 2015]. ISSN 1042-444X. Dostupné z: https://www.sciencedirect.com/science/article/pii/S1042444X15000092

[11] RAMÍK, J., 1999. Vícekriteriální rozhodování - analytický hierarchický proces (AHP). 1. vyd. Karviná: Slezská univerzita v Opavě. ISBN 80-7248-047-2.

[12] SAATY, T. L., 2006. Fundamentals of Decision Making and Priority Theory with the Analytic Hierarchy Process. Pittsburgh: RWS Publications. ISBN 0-9620317-6-3.

[13] SAATY, T. L., 2009. Theory and Applications of the Analytic Network Process: Decision Making with Benefits, Opportunities, Costs, and Risks. 2nd ed. Pittsburgh: RWS Publications. ISBN 1-888603-06-2.

[14] SAATY, T. L., 2010. Principia Mathematica Decernendi: Mathematical Principles of Decision Making: Generalization of the Analytic Network Process to Neural Firing and Synthesis. Pittsburgh: RWS Publications. ISBN 978-1-888603-10-1.

[15] SAATY, T. L., 2012. Decision Making for Leaders: the Analytic Hierarchny Process for Decisions in a Complex World. Pittsburgh: RWS Publications. ISBN 0-9620317-8-X.

[16] THOYTS, R., 2010. Insurance Theory and Practice. Abingdon: Routledge. ISBN 978-0415-55905-8.

[17] VÁVROVÁ, E., 2014. Finanční ř́zení komerčních pojištoven. 1. vyd. Praha: Grada Publishing. ISBN 978-80-247-4662-3.

[18] ZMEŠKAL, Z., 2012. Application of decomposition multi-attribute metrhods AHP and ANP in financial decision-making. In: Managing and modelling of financial risks $6^{\text {th }}$ international scientific conference. Ostrava: VS̆B - Technical University Ostrava, s. 689699. ISBN 978-80-248-2835-0.

[19] ZMEŠKAL, Z., 2014. Application of the Group multi-attribute decision-making methods in financial management. In: Managing and Modelling of Financial Risks $7^{\text {th }}$ International Scientific Conference. Ostrava: VŠB - Technical University Ostrava, s. 904-913. ISBN 978-80-248-3631-7.

[20] ZMEŠKAL, Z., D. DLUHOŠOVÁ a T. TICHÝ., 2013. Finanční modely: koncepty, metody, aplikace. 3. vyd. Praha: Ekopress. ISBN 978-80-86929-91-0.

[21] ZWEIFEL, P. and R. EISEN, 2012. Insurance Economics. Heidelberg: Springer. ISBN 978-3-642-20547-7.

[22] ČESKÁ ASOCIACE POJIŠŤOVEN. ČAP: Výsledky členů za rok 2018 [online]. ČAP [vid. 21. října 2019]. Dostupné $\mathrm{z}$ : http://www.cap.cz/images/o-nas/vyrocnizpravy/2018_vyrocni_zp.pdf

[23] ČESKÁ NÁRODNÍ BANKA. ČNB: Základní ukazatele o finančním trhu [online]. ČNB [vid. 23. ř́jna 2019]. Dostupné z:

https://www.cnb.cz/cnb/STAT.ARADY_PKG.STROM_DRILL?p_strid=B\&p_lang=CS 